\title{
14 | Plant biotechnology and the rights of the poor: a technographic approach
}

\author{
PAUL RICHARDS
}

\section{A right to development?}

The vexed issue of plant biotechnology has been debated (in wealthy countries) largely in terms of risk assessment (is it safe?). Development policy experts and multinational companies (displaying varying degrees of self-interest) have attempted to reformulate international debate in terms of needs (Stone 2002). Attention is paid here to plant biotechnology from the perspective of human rights. A right is an entitlement protected by law. The existence of a right implies a duty-holder. Under international law, the state is the main duty-holder, but the international community at times intervenes where rights are not protected by states; for example, where local law and order breaks down. In what ways might human rights impinge upon plant biotechnology? The right to food is enshrined in international declarations. Arguably it has major implications for technology. A right to food could be taken to imply rights of access to relevant genomic information. It might also be invoked to protect the crops of the poor from unintended introgression from genetically modified (GM) crops (the claimed discovery of transgenic constructs in Mexican land races of maize has excited controversy along these lines; Quist and Chapela 2001). Duty-holders may include biotechnology researchers, especially in public sector organizations.

The approach adopted in this chapter is technographic (Richards 2000), as distinct from jurisprudential (see Mohamed-Katerere 2003). Technography is a label proposed by anthropologists and sociologists of technology (Woolgar 1998) to cover the description and analysis of technologies embedded within social situations, and to account for the ways in which this embedding affects agency, collectivity and technological function. Technography, in short, describes technologies from the point of view of how they are actually used, and not from the perspective of how they are supposed to work. The technographic case study in this chapter deals with the zone of post-war recovery in central Sierra Leone, where use of plants is embedded within social and cultural contexts of considerable complexity (Richards 1986). The aim of the technographic analysis is to grasp enough of these contexts to render key technological variables visible and 
tractable to analysis. Seed issues, it will be demonstrated, are an aspect of an acquired right to self-provisioning. The entitlements upon which this right is based become apparent only via analysis of farming practices. Current biotechnology strategies for rice (the main staple in the region) are assessed in terms of the extent to which they protect or undermine self-provisioning. The chapter does not seek to judge biotechnology. The purpose is to characterize the interests of rights bearers and analyse the responses of duty-holders, thus throwing some light on a debate that must take place between citizens and science if biotechnology is to align itself with human rights.

\section{Technographic case study}

The major human rights declarations cover the right to food and other social and economic rights (Klein Goldewijk and de Gaay Fortman 1999; Sengupta 2000). Starvation contradicts the right to life. But a declared right means nothing until it can be acquired. A peculiarity of the situation of the poor in rural African zones of post-war recovery is that the duty-holders - in the absence of a functioning state or viable market institutions - are the poor themselves. The basic entitlement is self-provisioning through subsistence agriculture. Humanitarian agencies may intervene, and thereby become temporary duty-holders, but can rarely supply all groups in the population. Typically, they practise a kind of triage - establishing feeding centres for the most acutely malnourished, providing temporary rations to some (displaced women and children, say) and leaving others to fend for themselves (perhaps the bulk of the population). The concern in this chapter is with this last group. How do they cope? What technological options or legal protections would activate or sustain capacity for selfprovisioning?

War in Sierra Leone and its impact on the rural poor Sierra Leone has in recent years taken last place on the United Nations Development Programme (UNDP) human development index. Not only is it the most impoverished country, it is also the most unequal, having surpassed Brazil in that dubious distinction. The huge contrast in life chances between a relatively small number of Sierra Leoneans controlling wealth from the country's alluvial diamonds and the impoverished masses is a root factor in the eleven-year civil war (1991-2002) between the Revolutionary United Front (RUF) and successive government regimes. The conflict came to an end through stalemate and war-weariness. A ceasefire was finally agreed in November 2001, and the disarmament of the factions was completed in January 2002. 
The earlier guerrilla campaign (1991-95) mainly disrupted rural communities on the Liberian border. After the 1997 coup, fighting later more or less divided the country along an east-west axis, with rebel forces controlling Freetown, the north and the Kono diamond fields, and government loyalists controlling rural areas in the south and south-east of the country. A roadless tract at the centre of the country under the arc of the Kangari Hills became a no man's land, separating junta forces along the Makeni-Magburaka-Kono axis in the north and the Civil Defence Force (CDF) in the south (from 1997 onwards).

Populations fleeing fighting in 1995-96 - during which time many villages were burnt - began to return in 1997-98, and were more or less fully re-established by 1999-2000, some within rebel areas subject to an international boycott on relief and others in government-controlled areas assisted by international humanitarian agencies. Porter (2003) refers to this boycott on relief as 'one of the most shameful episodes of humanitarian inaction of modern times', but it forced civilian populations to survive through their own initiatives, and now provides an insight into the right to food under conditions of self-provisioning (see below).

Rice genetic resources: a key to pre-war food security A pre-war study, based on field work in 1982-83 and 1987-88, showed that a significant contribution to the food security of indebted and marginalized farmers in Mogbuama, Kamajei chiefdom, came from management of rice genetic diversity (Richards 1986, 1995). Rice is an inbreeder, and produces a wide range of named, stable phenotypes, each with distinct agronomic properties widely recognized by cultivators. A range of varieties is used to exploit different soil and moisture niches along the upland-lowland continuum. Farmers also regularly observe and collect off-types for further adaptive experimentation (Jusu 1999; Richards 1986). Female farmers in the Gambia and male farmers in Sierra Leone are equal in their use of knowledge of rice varieties to exploit a mosaic of soils and moisture facets, but the same kind of interest is not found among male Gambian millet farmers, suggesting that the key factor is the agronomic plasticity of rice, not gender (Nuijten, pers. comm.).

Rice farmers in Mogbuama change varieties at regular intervals, but at any one time each cultivating household retains a portfolio of ten or more distinct types, to benefit from staggered output from three distinct niches (upland, lowland and mid-slope run-off/zone plots). Early rice (ripening in 120 days or less) is important as a pre-harvest hunger-breaker (Richards 1997).

Debt-prone farmers are especially concerned to experiment with early 